\title{
The Internal and External Governance of Cooperatives: Membership and Consistency of Values
}

\author{
Silvia SACCHETTI \\ University of Stirling, Stirling Management School, Institute for Socio-Management \\ Ermanno C. TORTIA \\ University of Trento, Department of Economics \\ EMES-SOCENT Conference Selected Papers, no. LG 13-15
}

$4^{\text {th }}$ EMES International Research Conference on Social Enterprise - Liege, 2013

Interuniversity Attraction Pole (IAP)

on Social Enterprise (SOCENT) 2012-2017

and 


\begin{abstract}
Cooperatives are characterised by mutual-benefit coordination mechanisms aimed at the fulfilment of members' participation rights. This ideal situation may find, in practice, obstacles within the internal characteristics of the cooperative as well as in the nature of relationship with other actors in the socio-economic environment. Building on evidence from the literature, the paper systematises and highlights some of the potential problems in the governance of cooperative firms concerning the accomplishment of cooperative mutualistic aims. In exploring the internal conditions that may affect cooperative performance, we focus in particular on the role of rules and incentives towards such aims. In synergy, when analysing the external conditions that may affect cooperative performance, the paper addresses possible sources of external control, such as those related to the nature of the business relationships between the cooperative and its production network. In taking into account both internal and external conditions, we consider an extended notion of governance, whereby those who impact on strategic decision-making are not to be searched only within the internal governance bodies, typically the board of directors or managers, but also outside the cooperative, as in the extended network of production relationships in which the organisation is embedded.
\end{abstract}

JE L Classification: L21, L23, L26

Keywords: cooperative firms, governance, incentives, motivations, production networks.

\title{
ACKNOULEDGEMENTS
}

We wish to thank Carlo Borzaga, Lorenzo Sacconi, and Vladislav Valentinov for useful comments and advice on previous versions of this paper. We thank Colin Campbell, Johnston Birchall and Richard Simmons, Roger Sugden and James Wilson for the insightful conversations on the topic. Usual disclaimers apply.

(C) Silvia Sacchetti (silvia.sacchetti@stir.ac.uk) and Ermanno Tortia (ermanno.tortia@unitn.it) 2013.Version of June 14 ${ }^{\text {th }}$, 2013; please do not cite without the authors' permission. EMES-SOCENT Conference Selected Papers are available on the EMES website (www.emes.net) and on the SOCENT website (www.iap-socent.be). These papers do not undergo any editing process. They are published with the support of the Belgian Science Policy Office, within an Interuniversity Attraction Pole (IAP) on social enterprise entitled " If not for profit, for what? And how? ». 
"Dilemmas nested inside dilemmas appear to be able to defeat a set of principals attempting to solve collective-action problems through the design of new institutions to alter the structure of the incentives they face. ... But some individuals and/or communities have created institutions committed themselves to follow rules, and monitor their own conformance ... to the rules in common pool of resources situations".

Elinor Ostrom (1990)

\section{INTRODUCTION}

Cooperative firms are understood as mutual benefit organisations created by self-organised principals. Their nature is given by the need to device mutual-benefit coordination mechanisms for the fulfilment of social rights and needs pertaining to non-investor stakeholders. Such needs would include, for example, the stability of employment and a fair wage for workers in worker cooperatives, access to financial support for small producers in credit cooperatives, adequate quality and product prices for customers in consumer cooperatives, re-investments of surplus in the cooperative and in the community.

This ideal situation, however, may find in practice, internal and external obstacles. Previous contributions have analysed the internal problems that afflict cooperation, for example in members' apathy towards participation, failure of democratic representation, mismanagement and lack of skills, opportunism and fraud (Hernandez, 2006; Cornforth, 2004; Spear, 2004; Birchall, 2002). A body of theoretical and empirical studies have accentuated, in parallel, cases of external constraints, as related to ill-suited legal frameworks, access to capital, production conditions and contractual requirements, bargaining and decision-making costs, or external controls of political nature (Russell, 1991; Ben-Ner, 1993; Book and Ilmonen 1989; Lima, 2007; Hernandez, 2006; Speckbacher, 2008; Wanyama et al. 2009; Birchall and Simmons, 2010). The idea of this contribution is to address specific governance-related elements which may distance the performance of cooperatives with respect to their values and mission, i.e. to democratically pursuing the welfare of its members.

The current concerns with the factual ability of democratically managed organisations to move towards their objective can be broadly traced back to general substantive problems of collective action in the pursuit of entrepreneurial objectives. The classical problems of collective action, highlighted in the seminal contribution by Olson (1971), can be broadly applied to cooperative firms as well. Free riding and other forms of ex-post contractual opportunism can be particularly dangerous in the case of firms characterised by democratic and horizontal governance, more than where hierarchical and vertical governance prevails. These traditional critical remarks have been counteracted by other arguments connected with the implementation of effective governance rules, which can be able to forestall free-riding by punishing defectors or by devising suitable incentive systems. This has been clearly addressed by experimental literature on the supply of public goods (Fehr and Schmidt, 1999; Fehr et al., 2002). In teamwork studies, peer pressure has been described as a coordination mechanism that reduces shirking and free-riding, therefore increasing the trustworthiness of the members of the cooperating team (Mohnen et al., 2008; Mas and Moretti, 2009). Experimental studies have also emphasised the role of intrinsic motivations, since intrinsically motivated actors are less likely to free-ride on the delivery of public goods as a form of collective, and compatible firm objectives (Meidinger et al., 2000; Degli Antoni, 2009; 
Hayashi et al., 2011). Indeed, some authors have found that free-riding carries less weight in cooperatives than in other organizational forms (Craig \& Pencavel, 1992, 1994; Bartlett et al., 1992).

Still, problems connected with democratic governance remain at various levels and contexts, and deserve deeper scrutiny. Some contributions have highlighted a crises of cooperative values, as reflected in the isomorphism of procedures adopted by management, or in membership apathy for example, which runs the risk of downplaying the role of membership and mining the sustainability of the cooperative (Cyert and March, 1983; Spear 2004). Although in general ethical behaviour can be reinforced by the values and principles of cooperation, internal governance failures can play against this, and represent a serious threat to the possibility of enhancing welfare through self-management. Cases of fraud, in worst case scenarios, jeopardise trust between members and management, as well as the cooperative reputation with the community.

In parallel, the representative function of cooperatives is affected from the outside by the interlocking relationships in which cooperatives position themselves as part of their production activities. Similarly to what happens with traditional for-profit firms, cooperatives do not work in isolation. Extending Coase's warning, neither traditional firms, nor cooperatives can be considered as islands of economic planning (Coase, 1937). Cooperatives are businesses which operate in the market and interact with its extent, structure and technology. Interconnectedness implies acknowledging, as in Richardson (1972), the complementarities of competences and assets that firms seek through networking. More fundamentally, interconnectedness requires a difficult task of balancing the cooperative values with those of other forms of governance, which can be typically found in the diversity of firms that populate the market and which shape the production network of the cooperative. The misalignment between internal and external incentive structures can represent a further threat to cooperative aims.

The key to capturing both external and internal governance conditions is in the perspective from which we look at governance. We consider an extended notion, whereby those who impact on strategic decision-making are not to be searched only within the internal governance bodies, typically the board that represents members or the management, but also outside the cooperative, in the policy context and extended network of production relationships where the organisation is embedded. A similar line of analysis could be extended, as in Ben-Ner and Van Hoomissen (1994) to other stakeholders, such as consumers, donors and sponsors. In the scope of this work, more specifically, we will focus on one particular set of external influences as defined by production network relations.

We consider internal governance first. Taking the perspective of ownership theory, we focus on traditional aspects of control and surplus distribution (less so on the transferability of membership rights which may or may not be an option for cooperatives) ${ }^{1}$ (Grossman and Hart, 1986). In particular, in Section 2 we summarise the nature of cooperatives. In Sections 3 and 4 we highlight some of the potential collective action problems that can arise internally around surplus distribution and appropriation. These two aspects are particularly relevant in the context of cooperatives and their assets. More so in continental European cooperative systems rather than in the Anglo-Saxon ones, assets represent the membership's common resources which need to be

\footnotetext{
${ }^{1}$ Different views exist on this, see Dow (2003) for a thesis supporting the alienability of membership rights, while other authors express a contrary position (Ellerman, 2005).
} 
preserved over time to give continuity to the organisation. Part of the assets are typically locked, which means that they cannot be sold, and grow cumulatively through annual surplus shares.

For example, in Italy not less than 30 per cent of the surplus must go, by law, to the firm's indivisible reserves, or locked assets, although individual cooperatives may decide to reserve a higher share, up to 97 per cent, whilst 3 per cent of the surplus goes to a national fund aimed at supporting the constitution of new cooperatives. Common law countries (e.g. United Kingdom, Canada, Australia and Unites States) differ since locked assets and indivisible reserves are rarely observed. Though common ownership is not explicitly outlawed, no legal constraints support the accumulation of indivisible reserves like in continental Europe. Forms of common ownership need to be explicitly enclosed in company regulations or in the statute. This legal setting implies a much higher degree of appropriability of the firm assets by members. Still our analyisis applies, since even when assets can be appropriated by individual members, control is a prerogative of the organised collective of members (Tortia, 2011).

In most countries, common assets are a specificity cooperatives, and given that they are subject to diverse approaches across institutional frameworks, we will address in details the role of rules and practices which define how control over the use of assets is exerted. Internally, an understanding of the role of rules in the management of common resources support the analysis of the internal governance elements that impact on the actualisation of cooperative values and aims. In fact, the rules that define governance both limit opportunistic behaviour whilst reinforcing membership rights. Rules represent therefore the trait d'union between individual values, motivations and aims on the one hand, and organisational values and objectives on the other. In our analysis of internal governance, we focus specifically on the economic relevance of rules, alongside two main dimensions: (1) the development and enforcement of self-defined rules, addressing, inter alia, the management of common resources and outcomes as well as the nature of incentives; (2) the effectiveness of such rules in promoting individual motivations in line with the mutual benefit aims of the organisation.

In Section 5 we then move to consider external forces influencing the aims and values of cooperatives, focusing in particular on the nature of production relationships, and extending our account of governance to inter-firm relationships. Building on the analysis of the nature of production networks in Sacchetti and Sugden (2003), we oppose production relationships based on direction to relationships based on mutual dependence. These two are paradoxical situations: in networks of direction strategic production choices are concentrated within the core firm, whilst in networks of mutual dependence firms collaborate reciprocally respecting each other's interests and values. Building on this analysis we suggest a stylisation of cooperative networks, given their peculiarities. In Section 6 we provide a synthesis by offering a systematisation of internal and external governance forces and characteristics, with the aim of providing a framework for understanding the conflicts and tensions that surround the conditions for effective membership and values in cooperatives.

\section{THE ECONOMIC NATURE OF COOPERATIVES}

Economic analysis has shown behavioural diversities not only in individuals, but also at the collective level between cooperative and for-profit firms. Profit does not represent an objective in cooperatives as in traditional corporations. More correctly, the net residual in cooperatives is to be regarded as instrumental to the pursuit of other objectives that have to do with members' 
wellbeing. At the most fundamental level economic returns and surpluses are used by cooperatives to guarantee survival and expansion of the organization. Beyond these basic objectives cooperatives strive to guarantee the desired level of members' wellbeing both in material and non-material terms. In fact, because of these reasons, cooperatives can be regarded as non-profit oriented firms. ${ }^{2}$ On the other hand, cooperatives are to be distinguished also from more traditional non-profit organizations, since members' wellbeing is the primary objective of cooperative firms, while traditional non-profits are characterised by wider societal aims, which are understood to stem at least partly from other-regarding preferences.

This interpretation marks some of their most fundamental institutional and behavioural features as against profit maximising firms. Profit maximisation typically depends on the economic nature and institutional features of investor-owned, business firms. The latter have been conceptualised as saleable objects (Putterman, 1988), which implies that owners aim at maximising market value and are in a position to sell the firm (or its shares) at the highest possible price. The maximisation of market value requires that expected profits are, in turn, maximised. In the case of cooperatives firms, the mechanisms at work are different from the above, depending on the different institutional set-up. Given their non-profit nature, external financiers have limited incentives to invest and to organize production in cooperatives, both because private returns to investment on specific assets are lower than in for-profit firms, and because the nature of control rights increases the risks of losses and of morally hazardous behaviours by the self-organised principals. This places the obligation to fulfil economic, financial, and organisational requirements directly on the self-organised membership.

To illustrate, let us consider the Italian and the Spanish legislations as two specific cases in which explicit emphasis is placed on the non-profit orientation of cooperatives. In particular: (1) cooperatives are required to reinvest at least part of the net surpluses in asset-locked reserves that are exclusively owned by the organisation and cannot be appropriated by members also in the case of de-mutualisation and/or sale of the firm; (2) members rights are personal rights and cannot be sold as such in the market. In other words, the market for membership rights is excluded by customs or severely restricted by law. Both categories of institutional constraints make the sale of the firm more difficult and less convenient, deadening the tendency to consider the organisation as a saleable object. Starting from the seminal contributions by Furubortn \& Pejovich (1970), and by Vanek (1970), these features have attracted serious criticisms against cooperative firms, since they have been considered the source of dynamic inefficiencies in the allocation and accumulation of self-financed capital funds (Bonin, et al., 1993). These considerations were initially referred to the economic system of the former Republic of Yugoslavia, and then extended to all the forms of cooperative firms characterised by the accumulation of capital in asset-locked reserves. However, while the ensuing phenomenon of under-investment and under-capitalisation has found weak empirical support (Bartlett, et. al, 1992), these contributions have failed to recognise the positive functions of the asset lock, and to evidence its coherence with the non-profit nature of cooperatives.

Given their institutional features, the study of cooperatives would require specific conceptual and analytical tools that can be only limitedly drawn from the more traditional approaches to the study of the firm (Borzaga et al., 2011 ). Indeed, new conceptual frameworks that study cooperatives "in

\footnotetext{
${ }^{2}$ On the other hand, cooperatives are to be distinguished also from more traditional non-profit organizations, since members' wellbeing is the primary objective of cooperative firms, while traditional non-profits are characterised by wider societal aims, which are understood to stem at least partly from other-regarding preferences.
} 
their own terms" are canalising further research efforts. More specifically, rather than an investor focus, what is envisaged is a membership focus as the starting point of the analysis (Birchall, 2010). Such a shift has prompted concern for efficiency which, despite being transversal to all organisational forms regardless of who holds ownership rights, has been identified as a major shortcoming of the absence of investors. Most of the analysis, however, has tended to polarise, on the one hand emphasising an ideal model of cooperation in a hagiographic way or, conversely, devaluing their role and results with ideological arguments (Borzaga, et al., 2011). While some critics have evidenced a general lack of production efficiency in cooperatives, other empirical tests do not support this conclusion and stress the competitive potential of this form of enterprise. Specifically, cooperatives have been also shown to be able to reach high degrees of production efficiency, at times outperforming profit maximising firms (Bartlett, et al., 1992). The membership approach has the value of explaining evidence that is starkly in contrast with the predictions of the most traditional approaches to the study of the firm. In particular, being "member-centred organization," cooperatives are in a position to implement effective coordination mechanisms that favour the mutual alignment of members' motivations and ends on the one hand, and organisational values and objectives on the other, thus fulfilling members' participation rights. The motivational side of organizations, has been poorly understood by the economic orthodoxy and was rediscovered only recently with the growth of behavioural and experimental economics (Borzaga et al., 2011). The specificity of members' motivations has been thoroughly studied in particular in workers cooperatives, showing that these organisations tend to protect employment to a larger extent than capitalist firms and, to this end, worker members are ready to accept wages that fluctuate more than the wages received by workers employed in capitalist firms (Craig \& Pencavel, 1992, 1994; Pecavel, et al., 2006; Burdin \& Dean, 2009). Consistent attitudes can be found in cooperative banks as well, whereby the original mission tend to be one of providing financial support to small producers, who would otherwise be rationed by commercial banks. Overall, behavioural arguments endorse the specific role of cooperative and other-regarding attitudes, showing that rules that reflect the shared values of participants and support consistent motivations allow the organisation to achieve satisfactory monetary outcomes (Becchetti et al., 2012). Production efficiency, therefore, comes to depend on incentives that respect shared values, besides monetary sources. On the contrary, when shared values are infringed the sustainability of the organisation is endangered.

\section{SOME EMPIRICAL CONSIDERATIONS ON COOPERATIVE VALUES AND MISMANAGEMENT}

The cooperative ideal is centred on the specific nature of membership welfare, to be pursued through the values of open democratic governance, autonomy and independence, and concern for community (ICA, 2012). Where profit is not the primary objective, rules defining corporate governance become functional to the accomplishment of those specific values and welfare aims. It follows that the values and corresponding motivations endorsed by self-organised principals (either when creating, developing or adhering to the organisation) should be consistent with those of the cooperative ideal. Recognising the specificity of individual motivations in cooperatives, the incentive system should then be compatible with the underlying values protecting and fostering long-term sustainability and membership autonomy, inclusion, trust and reciprocal behaviour.

The reality of cooperative experiences does not always match this ideal. In practice, a number of issues still call for critical enquiry. For example: failures to reach mutualistic objectives; instances of misalignment between individual and organisational objectives; the spread of opportunism and 
breakdowns in coordination engendered by contrasts between different members or between members and managers. The difficulties attached to formal democratic governance are recurring in cooperative firms and have cast doubts on whether cooperatives represent welfare-increasing governance solutions. Indeed, some authors have authoritatively recognised in the limitations of cooperative governance a source of inflated governance costs, making cooperatives less viable and efficient solutions than investor owned organizations (Hansmann, 1996). From a slightly different angle, other approaches acknowledge the paradoxes of formal democratic governance, as for example in Cornforth (2004) and Hernandez (2006). These approaches recognise the incommensurable tensions that typify internal relationships between groups with different roles, such as between the board and the membership, which the board should represent; or between the board and the management, where the board's role is to assess managerial choices against the best interests of the membership. The relationship between the membership, the board and the management contains inherent tensions as it involves both support and control (Cornforth, 2004). Such tensions, as Hernandez (2006) explains in the context of a large Mexican cooperative, are ongoing in the decision-making process at different levels of governance (the board, the management, the general assembly), which paradoxically encompass both democratic participation and concentration of control power within restricted groups. In these contexts, democratic governance can be recognized as intrinsically dialectic, and the generation of excessive governance costs as a constant risk to be kept at bay.

Threats to democratically managed firms may come also from lack of effort in providing or renewing appropriate platforms for participation and engagement (Spear, 2004), but also from the opportunism of the membership, rather than from managerial bias. Managerial slack and members' disengagement, however, are likely to be related. Consider, as another illustration of misalignment between membership and cooperative values, reports from the United Nations Food and Agriculture Organisation (FAO). FAO has long aimed at increasing the welfare of farmers and communities by promoting rural cooperatives. In emphasising the limits of the cooperative model, FAO's reports have pointed at the dangers associated with members' shorttermism, for example when users put pressures on the cooperative to distribute patronage refunds rather than re-investing them in the cooperative (Von Pischke and Rouse, 2004).

An understanding of the reasons of membership disengagement from cooperative values, however, requires greater attention to the conditions and history of the organisation. Individualistic attitudes may be related not just to the close horizon of members but, under particular circumstances, to frustration, lack of confidence or trust in the cooperative, following previous experiences of members whereby their opinion has not been valued, or to mismanangement, or fraud. Other studies on agricultural cooperatives in developing and transitional countries have emphasised cases of abuses and misalignment between managerial and membership values, which led to the dissipation of members' confidence and trust in the cooperative. Jamsen and colleagues' study on Kenyan farmer-owned cooperatives highlighted agency problems of this sort, which have been argued to be possibly mitigated by improved transparency and financial reporting, paired by the commitment of public authorities to enforce anti-fraud legislation (Jamsen et al., 1999; see also Kandathil and Varman, 2007 on the substantive role of information sharing and trust in reinforcing formal ownership). These cases exemplify situations in which the inability of working rules and of public control to deliver effective solutions to governance dilemmas can engender vicious spirals that eventually endanger the viability of the cooperative venture as a whole. This is the problem to which we now turn. 


\section{INTERNAL RULES AND THE EXPRESSION OF COOPERATIVE VALUES}

The basic institutional structure of the organisation is typically defined by law and requires compliance by the members of cooperatives. There is, to put it differently, a broad institutional framework which provides part of the organisational rules. These reflect a number of consolidated values to which the principals choose to adhere in the first place. Variations, however, occurs. Governance and working rules specific to each single organisation are usually inscribed in routines embodying organisational protocols, and in other forms of self-regulation, depending on members' discretionary decisions (Ostrom, 1994). In fact, we could argue that change in the rules occurs thanks to the tensions that inevitably originate from experience. Such tensions can exist, to different extents, despite the level of specification of the legal framework or of internal rules. Both in fact can be progressively refined to acknowledge their interaction with the practical conditions and outcomes of self-managed activities. Within the organisation, in particular, formal rules but also routines and shared practices are subject to change. The open-ended nature of institutional evolution has to do, in this case, with the ever changing features of rules inside each single organisation and relates to the firm's survival and expansion potentials. We refer here to the concept of ontogenetic evolution, more than to the concept of phylogenetic evolution of the institutional set-up of the organisation (see Hodgson, 2006).

Legal and self-defined rules together identify criteria for managing the cooperative assets and distributing returns. The multiplicity of perspectives on how to achieve members' welfare through resource allocation, can generate, as pointed out by Cornforth (2004), tensions among board representatives, managers, and members, as well as within each of these groups, the reason being that the utilisation and distribution of surplus is "subtractive" (Ostrom 2010). In particular, this engenders trade-offs which, in the absence of proper regulation, can become unsolvable social dilemmas. Self-defined rules have, therefore, a clear place in guiding the appropriation of resources and preventing the exacerbation of conflicting interests. Although they may not represent a solution to all possible intrinsic organisational tensions, they are bound to underpin any collective economic activity. In designing internal rules, self-managed principals can employ their detailed knowledge of the production process and of the socioeconomic context to design rules which are more effective in terms of their propensity to lead to desired results than what external regulators would be able to achieve (Ostrom, 2010).

This, however, would be a sheer possibility where such knowledge is not accessible by the members, for example when communication is not embedded in the practices and culture of the organisation and, as a consequence, interests or other information are not openly communicated and discussed. In particular, the cooperative could have poor levels of social capital and trust, or members may not effectively codify tacit knowledge or may not use such knowledge effectively, for example because of managerial slack, lack of will or gaps in their expertise and intellectual capital (Ostrom, 2010; Nahapiet and Goshal, 1998; Grant, 1996; Kogut and Zander, 1992).

Over time, whilst using in-built rules as empowering features for the membership, cooperatives need to monitor, identify and foreclose inconsistent behaviours that would hamper the survival of the organisation as much as the motivation of other members. Ideally, when reflecting the needs, values and objectives of members, regulation enables common activities to develop consistently with individual fulfilment. Recalling the work of Commons (1934, p.70), institutions empower individuals, being "collective action controlling, liberating and expanding individual action" 
(quoted in Mirowski 1987, p. 1020). We regard therefore internal governance as a set of rules, derived by the law and by internal governance choices, that are functional to the expression and accomplishment of cooperative values and to increased members' well-being, and whose role is to provide a space where individual motivations and aims on the one hand, and organisational values and objectives can meet.

Internal rules include incentives, both monetary and non-monetary. These can contribute to reinforce the interdependence between individual motivations, the nature of the cooperative collective resources, as well as organisational values and objectives more generally. A non secondary consequence of misalignment between individual motives and organisational rules, which restates the relevance of incentives differently from the more traditional performancerelated view, would be the emergence of X-inefficiency (Leibenstein, 1966), for example in terms of members' reduced involvement and commitment, or individual pursuit of aims at odds with organisational objectives. Because of these reasons, control costs would rise. Orthodox approaches have prescribed a number of remedies, ranging from increasing hierarchy to tightening control and pay for performance (Lazear \& Shaw, 2007). All these cures are liable of increasing costs without guaranteeing expected efficiency (Frey \& Osterloh, 1999). More fundamentally, however, these solutions increase the distance between membership and management, damaging deliberative processes, and favouring instrumental interactions (Sacchetti et al. 2009; Ryan \& Deci, 2000)

Rather, self-organised principals are expected to choose a mix of incentives which reflects their specific values and apprises individual motivation sets consistently. In particular, it has been argued that monetary incentives should be adequately balanced with intrinsic ones, and match individual motivations which do not have a specific monetary equivalent. The monetary and intrinsic aspects of individual motivation are not necessarily in conflict. Indeed, recent results coming from the analysis of workers' motivations in social cooperatives demonstrate that stronger intrinsic motivations are also linked to higher monetary remuneration (wages) via increased productivity (Becchetti, et al., 2012). This does not imply higher costs in cooperatives with respect to for-profit firms because the average level of wages is usually lower for the former (Pencavel, et. al., 2006). It follows that the positive alignment between individual intrinsic motivations, for example concerning involvement, and organizational objective does have competitive potentials.

\section{COOPERATIVE VALUES AND THE GOVERNANCE OF PRODUCTION NETUORKS}

So far we have touched some of the major challenges to internal governance, where rules on the management of assets, surplus and incentives mitigate the tensions between the values and objectives of the organisation on the one side, and individual motives on the other, across different groups of actors. Choices on asset management and incentives however are likely to be influenced also by the market context and by the types of production relationships in which the cooperative is involved.

Drawing on the insights of Penrose (1959), in his seminal contribution, Richardson (1972) suggests that the firm and the market are not the only means for co-ordinating production. Rather, production is organised also around 'complex networks of co-operation and association' amongst firms which may take different forms and with varying degrees of cooperation amongst firms. Richardson attached the substance of cooperation in business to the nature of the activities 
undertaken and to the capabilities which define what each firm can do. It follows that the coordination of production across firms, rather than being left to the market only, is an intentional strategic choice (Penrose 1995 [1959]). More substantially, the position that the firm occupies in the production network and the characteristics of interaction within the network have been argued to have governance implications in terms of who determines strategic choice and how problems are addressed (Markusen, 1996; Sacchetti and Sugden, 2003; 2010; Humphrey and Schmitz, 2004; Parrilli and Sacchetti 2008). The location of strategic decision-making power, in particular, could be placed, to some extent, outside the organisation, such as for example when a relevant part of the firm's activities are channelled within exclusive relationships that place the costs of asset specificity on the firm. Sacchetti and Sugden (2003) suggest a paradox approach to the analysis of networks, opposing two extreme situations. The first is one of subordination to the strategies of the core firm in the network ("networks of direction"), where decisions affecting other firms in the supply chain are taken despite the other firm's interests. The second is one of mutual and reciprocal collaboration, where decisions about the coordination of resources that have implications for partners are subject to a process of deliberation, emphasising communication and learning ("networks of mutual dependence"). Between these two extremes, as exemplified in Parrilli and Sacchetti (2008), we can observe a variety of situations, with firms engaging with a multiplicity of partners holding different degrees of control power and governance implications.

Cooperatives operate across sectors, from agriculture to manufacturing, services and retailing (Hansmann, 1996; Birchall 2011). Each sector presents specificities both in terms of membership needs, organisation of production and market structure. The scale of activities in particular and the sectorial characteristics, in general, contribute to define how firms choose to organise production within and across their organisational boundaries (Menzani and Zamagni 2010). For example, taking the case of Italy, the relevance of large cooperatives (with at least 500 workers) is particularly evident in food and beverages manufacturing, banking, retailing, tourism and restaurants, whilst small and medium cooperatives (SMCs) concentrate in the provision of health and social services, information and communication services, education as well as in constructions and transports. ${ }^{3}$

The multiplicity of sectorial needs and sizes, combined with the cooperative values, hints at the variety of governance solutions that cooperatives can adopt both internally and externally. Below we suggest a typology of networks which is aimed at clarifying diversity in the nature of relationships between the cooperative and other firms, and the implications for the membership. For each network type we focus on three specific elements (Table 1):

a) The distribution of control over production resources;

b) The degree of tension existing between power distribution and the objectives of the membership within each cooperative in the network;

c) The degree of consistency between the objectives of the membership and the values of cooperation more broadly.

\footnotetext{
${ }^{3}$ Data are available from ASIA (Statistical Archive of Active Enterprises) and refer to active businesses in manufacturing, construction and services, excluding cooperatives in agriculture, forestry and fishery. For a detailed analysis see Unioncamere (2010).
} 


\section{Table 1 - Typology of networks involving cooperative organisations}

\begin{tabular}{|c|c|c|c|}
\hline Network features & Instrumental hub-led network & Cooperative hub-led network & State-anchored network \\
\hline $\begin{array}{l}\text { Structure } \\
\text { Defining the nature of network } \\
\text { relationships. }\end{array}$ & \multicolumn{2}{|c|}{$\begin{array}{l}\text { A core firm with a number of contractual or financial linkages } \\
\text { with other cooperative or investor-controlled companies (which } \\
\text { can take the form of a group). } \\
\text { Networked firms are generally functional to the activities and } \\
\text { strategies of the core cooperative. }\end{array}$} & $\begin{array}{l}\text { Public administrations are the core } \\
\text { organizations demanding welfare services, } \\
\text { typically to SMCs. }\end{array}$ \\
\hline $\begin{array}{l}\text { Power distribution } \\
\text { Who controls production resources } \\
\text { and the common assets of the } \\
\text { network, if any. }\end{array}$ & \multicolumn{2}{|c|}{$\begin{array}{l}\text { The core cooperative tends to consolidate control beyond } \\
\text { internal membership either through contracts and practices or } \\
\text { through ownership. } \\
\text { Strategic decision-making power is concentrated in the core. } \\
\text { The core cooperative controls network resources. }\end{array}$} & $\begin{array}{l}\text { Demand for services depends mostly on } \\
\text { public welfare policy. } \\
\text { The public defines the rules and community } \\
\text { welfare standards. } \\
\text { Asset specificity in SMCs to meet public } \\
\text { welfare standards. }\end{array}$ \\
\hline $\begin{array}{l}\text { Consistency of values } \\
\text { Whether the values of cooperation } \\
\text { are reflected in the internal } \\
\text { governance as well as in network } \\
\text { governance. }\end{array}$ & $\begin{array}{l}\text { The values of cooperation are } \\
\text { applied within the core to } \\
\text { some extent, but not externally, } \\
\text { with respect to other } \\
\text { organizations. }\end{array}$ & $\begin{array}{l}\text { The values of cooperation are } \\
\text { applied, to some extent, within } \\
\text { the core, as well as externally, } \\
\text { to inter-firm relationships. }\end{array}$ & $\begin{array}{l}\text { Public sector objectives and values may be } \\
\text { expected to be compatible with the values of } \\
\text { cooperation promoted, in principle, by } \\
\text { SMCs. } \\
\text { Consortia of SMCs working as networks of } \\
\text { mutual cooperation, addressing public bids, } \\
\text { quality of services, training, debate. } \\
\text { Tensions within such consortia are addressed } \\
\text { through communication and debate, } \\
\text { consistently with the cooperative values. }\end{array}$ \\
\hline $\begin{array}{l}\text { Degree of tension } \\
\text { Due to divergence between the } \\
\text { internal interests (from the } \\
\text { membership or the management) } \\
\text { and power distribution within the } \\
\text { network. }\end{array}$ & $\begin{array}{l}\text { The interests of the core } \\
\text { cooperative are pursued even } \\
\text { disregarding those of other } \\
\text { cooperatives and traditional } \\
\text { firms in the network. } \\
\text { Tensions amongst firms are } \\
\text { addressed through processes } \\
\text { that emphasize authority and } \\
\text { control. }\end{array}$ & $\begin{array}{l}\text { The interests of the core } \\
\text { cooperative are pursued } \\
\text { considering the implications } \\
\text { for other firms in the network. } \\
\text { Tensions are part of the } \\
\text { interaction amongst firms, but } \\
\text { they are addressed through } \\
\text { processes that reinforce } \\
\text { communication and enquiry } \\
\text { rather than authority and } \\
\text { control. }\end{array}$ & $\begin{array}{l}\text { Risk of SMCs failure in delivering public } \\
\text { welfare standards is addressed via: } \\
\text { - Multi-stakeholder membership } \\
\text { within SMCs; } \\
\text { - Reporting and monitoring } \\
\text { Risk of public failure or vested interests in } \\
\text { public administrations: } \\
\text { - Role of consortia in compensating } \\
\text { for public failure and promoting } \\
\text { change in the public-private } \\
\text { relationship. }\end{array}$ \\
\hline
\end{tabular}




\subsection{Hub-led networks}

Consider industrial cooperatives, and in particular the case of coordination by means of financial integration or by means of contractual agreements, such as those regarding subcontracting relationships that may link industrial cooperatives with other organisations, including traditional for-profit firms. The tightening of coordination can define strategies of financial integration and, in the case of the largest cooperatives, the creation of groups where the core cooperative holds financial control or minority participations in a number of other firms (which can be cooperatives but also traditional for-profit organisations). This is the case for example in producer/worker cooperatives in sectors such as construction or manufacturing. Because of the technology, fixed costs and scale of their activities, these cooperatives tend to integrate other companies, regardless of their profit or non-profit nature, through shareholding. Such strategy has supported in particular capital accumulation, allowing cooperatives to raise capital through traditional forprofit companies (Cf. Menzani and Zamagni 2010 for a historical account in the Italian context). The activities of controlled companies are in general functional to the main activity of the leader firm, although they may not be directly related to it. At the same time, with the principal aim of increasing flexibility, the core also operates by means of subcontracting agreements and collaborations or, particularly in constructions, by forming temporary consortia for the delivery of particular projects, generally holding a substantive quota in each consortium. In these cases, the principal cooperative would issue a tender for aspiring collaborators or subcontractors, setting the quality standards in line with its own ethos and with the original features of the project to be delivered.

When acting as core firm, the cooperative may manage subcontractors in different ways. In fact, we could say that the greater the distance from the perfectly competitive market benchmark, the higher the relevance of firm behaviour and, therefore, of the governance structure for defining corporate strategy. In the specific case of cooperatives, substantive practices and external influences, besides ownership, can impact on strategic choices, more or less consistently with cooperative membership values. It follows that, depending on the market structure and type of competition, and despite its non-for profit nature, the cooperative could, as a possibility, seek monopoly power or collusive agreements with other producers. Such strategy would be at odds with the fundamental aims of a consumer cooperative, for example, which is typically created to prevent the price and quality disadvantages of monopoly power in food retailing. Moreover, where the competitive element is more incisive, strategy may focus further on permanent cost minimisation by stimulating arm's length market competition among substitutable producers, typically for low knowledge content production types. Conversely, the core can cultivate more complex collaborative contractual arrangements with complementary suppliers that hold strategic relevance. In both cases, given the market structure, the modalities of the interaction may be similar to those of the for-profit sector or, more generally, to governance by direction, where relationships are administered strategically without a proper account of the interests of other firms (Sacchetti and Sugden, 2003).

These governance arrangements blur the fine line between the internal and external governance values, and deserve empirical consideration. The distribution of the residual rights to control network resources clearly places controlled companies in a subordinate position. In line with the strategic governance approach earlier developed by Cowling and Sugden (1998), we suggest, in 
particular, that the extent to which the power differential is used to take strategic decisions despite the desires of the subordinates provides an indication of the consistency between the objectives of the core's membership on the one hand, and the values of cooperation more generally on the other. The tension would be between the interests of the core's members and the values embodied by the core's network strategy. Again, the fine line between internal and external governance values would be crossed if the core cooperative employs controlled firms, subcontractors or suppliers with the aim of externalising labour conditions that do not suit the interests of the membership.

One reason for subcontracting activities, besides the search for complementary knowledge, can be to increase output without having to expand the organisation. Because cooperatives are not owned by investors, raising financial capital through conventional shareholding is not an option. By acquiring new subsidiaries or reverting to subcontracting, the cooperative, in fact, does not need to hire more non-member employees and to raise new capital through membership, which can prove to be difficult for instance when growth occurs across localities and diverse workrelated cultures. ${ }^{4}$ At the same time, similarly to what happens with controlled companies, the core cooperative retains flexibility against market changes; eventually leaving the problem of lay-offs to the subcontractor, or the controlled company. In this sense, the stability of employment in production cooperatives needs to be weighted against the implications of its networking strategies, controlling in particular for the distribution of the negative externalities of self-managed organisations on for-profit subcontractors and subsidiaries.

In such cases, we can talk of an instrumental hub-led network, when managerial choices reflect, to some extent, the values of democratic governance and members welfare on the one hand, whilst at the same time confine those principles within the cooperative organisational borders. Both internal governance (through financial integration and group formation) and other production relationships, in this particular case, would be functional to the objectives of the core cooperative and particular groups within it, even despite the welfare of controlled companies or subcontractors. Conversely, we call cooperative hub-led network a network where the principal cooperative applies its core values to external governance, actively searching for compatibility between the objectives of its membership and the interests of other stakeholders. The application of the cooperative values to other firms would add consistency to the organisation also internally, although this may increase the tensions between those who perceive the cooperative as being essentially about the welfare of members and those who would regard others outside the cooperative as subject to similar principles. We set this as an ideal, against which to contrast the reality of hub-led networks, typically structured as cooperative groups or holdings. When the cooperative's strategy is to coordinate its different sets of relations on the ground of cooperative principles more generally, external governance would recognise, through appropriate mixes of financial participation, contractual arrangements and substantive practices, the desirability of coordinating production on a mutually supportive basis, where each organisation can learn, create further knowledge, voice and address issues of concern on the ground of specific shared values (Sacchetti and Sugden, 2009).

Instrumental versus cooperative attitude towards production relationships, for example, have represented the controversial aspect of the expansion and internationalisation of the Mondragon

\footnotetext{
${ }^{4}$ Workers cooperatives, for example, are required not to fall below a given member-employee ratio which can be discretionally set by the cooperative, consistently with legal prescriptions (the latter, in some countries like Italy, may include a "prevailing mutuality" principle, which is a necessary condition to obtain also some fiscal advantages).
} 
Cooperative Corporation, the Basque cooperative group which, since its foundation after WWII, has in many respects pioneered the articulation of a system of organisational rules alongside the cooperative values. Despite its values, internal and international growth has not happened without tensions. In particular, the expansion of its industrial and retail sectors overseas was shaped by a strategy of acquisitions and green-field investments for the creation of subsidiaries, without worker membership. This type of FDls have reflected a strategy of cost minimisation, but also risk reduction in the face of diverse workers attitudes regarding employee ownership across countries, and different legal frameworks. In fact, Mondragon has adopted a strategy towards internationalisation which was similar, in some respects, to those of traditional transnational corporations (Errasti et al. 2003). The growth strategy of Mondragon has raised an issue around the values of cooperation, where the pursuit of members' welfare becomes a cost for other workers inside controlled or otherwise affiliated companies. Tensions between membership and management on such matters may run the risk of damaging, in particular, the trustworthiness of the cooperative as well as members' motivations. The challenges to the idea of membership presented by growth and internationalisation are currently unresolved, but likely to change again the architecture of rules at Mondragon. More recently, in fact, members in the home country (Spain) have voted to support the extension of membership rights to workers overseas, gradually starting a process aimed at reducing control beyond membership rights. Whether however it is the management driving governance choices or rather the membership would require empirical investigation on a case by case basis.

Interestingly enough, it appears that, after a relevant span of time, the Mondragon system appears still able to discuss the extension of internal and external democratic governance rules to affiliated firms abroad, and to start processes of reform of its overall governance settings (Jones and Kalmi, 2012). More generally, it appears that the development of both internal and external democratic governance requires complex operations of social reconstruction that, as the Mondragon experience shows, often take place in the institutional void and require long elaboration in a pragmatist perspective (Morrison, 1991; Stikkers, 2011).

\subsection{State-anchored networks of cooperatives}

Let us now consider the provision of social services and the frequent situation of the public sector working as the main contractor of local social services cooperatives. Echoing a terminology used by Markusen (1996) for industrial clusters, we name networks driven by public demand for services state-anchored networks of cooperatives, with objectives mostly influenced by the welfare policy and standards set by policy makers. The cooperative may, in this case, develop a high level of sunkness with respect to the public sector and its demand for services, which set the standards and the necessary investments, both in material and intrinsic assets such as human capital. The degree of specialisation of the service provider occurs within the context defined by the rationale, objectives, standards and coordination methods of public administrations. Consider the case of Italy, where social cooperatives are a remarkable feature of the welfare system. On average, each of the over seven thousand cooperatives will have three agreements with the public sector (typically municipalities and the public health system) and one with a private non-profit firm (i.e. another social cooperative or a voluntary organisation). As a reflection, 69.3 per cent of turnover comes from contracts with the public sector (out of a national total of 6,381,275 Euros; ISTAT, 2008). 
What these specific data suggest is that as demand for social services originates from communities and is regulated by public administrations, the members and management of a social cooperative, in fact, address the distribution of resources within the framework defined by the public sector, which is expected, at least in principle, to be set in the pursuit of the public interest, rather than despite it. In the UK, for example public procurement rules tend to favour social enterprises, which can be cooperatives, where these can effectively provide social services to the community, as illustrated by the explicit introduction of a community interest clause for public procurement bids. Within the procurement framework public administrations have the duty to promote, incentivise and monitor the quality and economic sustainability of provision. ${ }^{5}$ Specific policy towards the achievement of quality results, and their communication by means of adequate reporting and accountability provide social cooperatives and public administrations an opportunity to learn and innovate on the services, as well as to find a sustainable balance between social objectives and economic sustainability (see Gibbon and Dey, 2011 for a discussion).

More radically, the members of a social cooperative (typically workers) can opt for a multistakeholder type of governance, implying a direct involvement of major stakeholders, e.g. users, volounteers, professional associations, and institutions (e.g. job centres) in the board of directors (references to Becchetti and Borzaga, 2010). Multistakeholder governance (as against monostakeholder governance) internalises the stakeholder network in the governance of the social cooperative. In this way it addresses the potential tensions between the community demand for social services and the interests of the cooperative membership directly, by placing the process of coordination of resources and interests at the heart of the cooperative structure. This may lead also to greater consistency among the objectives of the membership, the performance of provision, and the application of the values of cooperation to external relations, e.g. in formal and informal agreements with other private businesses.

Dependence on the public sector however can be an issue when macro strategies change or in the presence of public failure. The success of social cooperatives in obtaining and renewing contracts with public administrations may not be uniquely related to their efficiency and ability to achieve desired social objectives. At the macro level such possibilities are subject to changes in public policy and governmental approaches to the provision of welfare services. The efficiency of public administrations and macro-economic circumstances under which governments operate are also an issue for small social cooperatives. The recent debt crises has brought to the surface cases of reduction of contracts for service provision, as in the UK, or in delays in payments by public administrations, as in Italy, which have in turn made some social cooperatives insolvent and the beneficiaries of the services uncovered. Governments can in fact delay the introduction of particular norms regarding payment standards and other contractual conditions to their own direct advantage, externalising the costs of such delays to social cooperatives which are in fact financing the provision of welfare services. One of the largest consortia for social cooperatives in Italy is CGM, with 5,800 associate organisations. According to their estimates, in 2012 delays in payments from the public administration are around 2.7 billion Euros. 70 per cent of the associate cooperatives are affected by such delays (6 months on average) (CGM, 2012).

\footnotetext{
${ }^{5}$ In 2005 the production costs of Italian social cooperatives nationally were 2.4 per cent below the level of total turnover and $63.2 \%$ of social cooperatives made a surplus (ISTAT, 2008).
} 


\subsection{Small and medium-sized cooperatives (SMCs) and networking by consortia}

In Italy cooperatives have grown from 10,744 in 1971 to 55,700 in 2007 (Unioncamere, 2010; Bodini et al., 2010) and account for 1.2 per cent of the total number of enterprises $(0.5$ per cent in 1971) (data do not include the primary sector). With 1 million 97 thousand workers (these were 207,477 in 1971), however, they have a more important impact on occupation, accounting for 6.2 per cent of total employment. Still only 0.8 per cent of these occupy more than 250 workers, whilst 93 per cent operate with less than 50 workers (Unioncamere 2010). SMCs, which in fact represent the majority of cooperative firms across sectors, are likely to engage in relationships of the two above mentioned types (hub led networks; state-anchored networks). For example, a strong dependence of the SMC on an instrumental hub-led network runs the risk of hollowing out the bond between management and members, whilst exacerbating the yet intrinsic tensions between members welfare and economic sustainability. Less so for state-anchored cooperatives, where the type of direction provided by the public sector may be expected to have a number of contact points with cooperative values, and therefore to balance external pressures and internal values, although this aspect would have to be tested in practice as dependence on the public sector remains an issue.

Overall, an understanding of the effectiveness of membership and cooperative values more generally requires careful consideration of the nature of production linkages and in particular of the balance between relations based on cooperation and mutual support as against those based on direction. The latter would damage in particular the effectiveness of membership as direction would be functional to the objectives of an external core and despite the welfare of financially controlled firms, suppliers and subcontractors, beneficiaries and communities more broadly.

Since for SMCs the value attached to participation by the membership is in general higher (Spear, 2004), it follows that a cooperative network based on small sized cooperatives is likely to reflect more accurately the values of membership. Social capital and, at a more formal level, consortia have been an important feature of the development of cooperatives in Italy for example, playing as a major networking mechanism for either large or small organisations (Menzani and Zamagni 2010). They have grown in different sectors as grass-root networking organisations to represent cooperatives in the public debate, and support cooperatives in basic business functions. More crucially, consortia can contribute to reinforce the position SMCs in production networks, voicing interests and generating opportunities, helping to achieve the scale that is often needed to bid for private and public calls. For example, 80 per cent of the total turnover of social service cooperatives in ltaly is generated by enterprises that have joined cooperative business associations (ISTAT, 2008). In the case of small social cooperatives, CGM (Consorzio Gino Mattarelli) in Italy, has played a big role in promoting cooperative values, entrepreneurship and training, but also in accumulating financial resources (as "solidarity funds") which are aimed at supporting cooperatives that face particular liquidity difficulties. Consortia like this one is are in fact institutionalised networks that can take the form of a social cooperative like its member organisations, and present features that in a number of respects can become close to a network of mutual dependence, as in Sacchetti and Sugden (2003). 


\section{INTERACTION BETUEEN LAYERS OF GOVERNANCE}

The overarching message coming out of our discussion of production governance and its impact on membership has placed emphasis on the idea of interconnectedness between different layers: linkages exist not only conceptually but also empirically between individual motivations and collective values, formal and substantive aspects of internal governance, network governance, and the welfare of membership.

The reversed pyramid in Figure 1 exemplifies the interplay between the different elements in the framework. It accounts, in particular, for the interaction between the individual and the institutional structure (Hodgson, 2007). The organisation is represented as a stratified entity where the different layers interact through specific connectors: rules and norms of behaviour. At the first layer of the pyramid are the basic features of the market defined through institutional design, which usually undergo a high degree of legal formalisation concerning control and appropriation rights. Differently, the upper layers reflect the evolving propensities of individuals.

At the most fundamental level, control rights allocate control over the broad direction of the organisation and over the appropriation of the produce. The process of evolution of control rights is likely to take place in the long run (Williamson, 2000). It follows that control rights can be considered as given and their evolution framed in terms of ontogenetic, more than phylogenetic evolution (Hodgson, 2006). Control rights are binding in defining who has access to decisionmaking; however they do not univocally define how common resources (such as cooperative reserves) are managed. This pertains to the internal governance of strategic choice making, which is crucially influenced by the organisation's structure and working rules. The nature of governance, at this level, is chosen by the self-organised principals, reflecting their values and objectives. By framing values and objectives, self-regulation determines also the criteria for assessing behaviour. We identify therefore two complementary faces of self-regulation: the creative and the binding. If, on the one hand, the definition of rules leaves space for the expression of specific values and enables principals to creatively shape the organisation's governance, on the other hand rules have also constraining features. These are directed to foreclose opportunistic behaviour and guarantee a high degree of compliance with collectivelydefined objectives. The achievement of a fair environment is crucial in enabling participation, as the latter would work only when relations inside the firm are based on trust and reciprocating behaviours, since with participation each individual position is not independent from the positions and behaviours of the other members. The spread of opportunism can be particularly dangerous if intrinsic motivations are at the heart of activities. While in new institutionalism opportunism has a substantive role in individual behaviour (opportunism as self-interest seeking with guile in Williamson's words, in our framework opportunism represents juts one possible behavioural pattern (Williamson, 1987). The overcoming of opportunism is never to be excluded when proper controls and involvement procedures are designed. Hence opportunism is conceived as potential obstacle to the accomplishment of cooperative behaviours, and to the flourishing of individual motivations, more than as an ontological feature of all human beings. Opportunism can easily undermine the alignment of individual and collective objectives, endangering firm survival and growth. However, when opportunism is kept at bay by proper rules, members' rights to decisionmaking are expected to strengthen and to enable a more coherent expression of motivations, which, in turn, foster individual fulfilment, as well as organisational sustainability (Ostrom 2010; Ben-Ner and Jones 1995). 
Figure 1 - Cooperative organisations explained: the reversed pyramid of interconnections between governance and aims

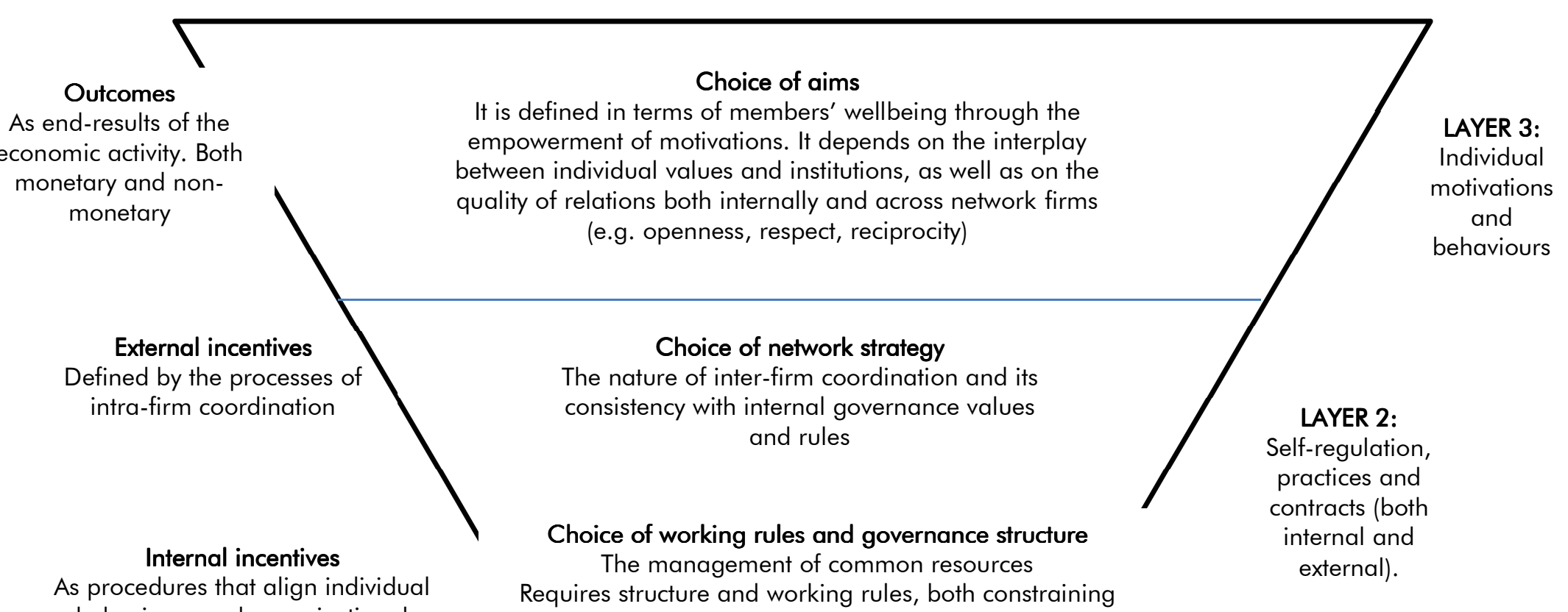
As procedures that align individual behaviours and organizational

$$
\text { objectives. }
$$

Monetary and non-monetary

\section{Legal Frameworks}

As available frameworks that define the allocation of control rights and

rights to appropriate returns

$$
\text { and enabling. }
$$

Rules emerge and develop to support the evolutionary potential of the organisation

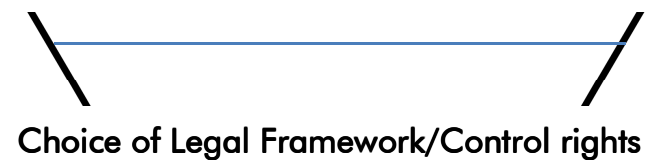

Choice of Legal Framework/Control rights

They define the basic decision making processes and appropriation

patterns of self-organised principals

\section{LAYER 1:}

Fundamental

institutions; legally

binding constraints

\section{Values (those broadly shared by society; those selected and shared by self-organised principals)}


The constraining feature of rules is not meant to impair individual potential, but to ensure that each individual's right to participate and share results is respected. Rules that inhibit inclusion, from this perspective, would be perceived as unfair and have the undesirable effect of undermining intrinsic motivations. Intrinsic motivation is impaired also when rules are perceived as external to the individual (Frey, 1997). One way to align individual desires and organisational rules is to put in place processes of adjustment which can modify rules to reflect the evolving, shared needs of members.

In parallel, however, external arrangements such as those expressed through production linkages can interact with the internal choices of rules, by diluting (or reinforcing) the values of cooperation throughout the production chain. The nature of production linkages defines also the type of incentives for other firms in the network, which may experience, to different extents, the hollowing out of the strategic decision-making function. In the case of hub-led networks, the nature of the incentives set forth for subsidiaries, subcontractors and suppliers may in turn raise issues on the external consistency of cooperative values and on the role of membership. SMCs, on the other hand, are likely to be subject to dependence on their main contractors, whether those are private firms or public administrations. Again, where the decision-making power of the membership is subordinated to the strategies of third parties, the core values and objectives of the cooperative may be at risk, and likewise the motivation of members.

The intrinsic motivations of principals are located at the top layer of the scheme. The relevance of intrinsic motivations is clearly explained by Deci and Ryan (2000, p. xxx):

\begin{abstract}
"Perhaps no single phenomenon reflects the positive potential of human nature as much as intrinsic motivation, the inherent tendency to seek out novelty and challenges, to extend and exercise one's capacities, to explore, and to learn. ... The construct of intrinsic motivation describes this natural inclination toward assimilation, mastery, spontaneous interest, and exploration that is so essential to cognitive and social development and that represents a principal source of enjoyment and vitality throughout life".
\end{abstract}

Their full expression represents the highest attainment of the organisational structure insofar as it increases individual wellbeing and improves production performance. Our scheme, therefore, identifies the benchmark for assessing the combined action of control rights and working rules in enabling the full expression of individuals' inner motivations. Intrinsic motivations find spontaneous expression in each single individual. Here we highlight that their full expression in the organisational realm requires adequate institutional preconditions, which are likely to be particularly favourable in self-organised, mutual-benefit entrepreneurial ventures. This occurs if there is mutual adjustment over time between individual values and the values recognised by institutions.

\title{
7. CONCLUDING REMARKS
}

In developing our three-layer framework for explaining the links between governance choices, shared values and individual motivations, we have placed the individual dimension of motivations and needs at the basis of our pyramid. By reversing the pyramid up-side-down we have, at the same time, overturned the order through which we look at the elements underpinning economic decisions, to emphasise that the fulfilment of individual needs and the full expression of individual motivations is also a result of the interaction with the institutional and organisational spheres. In fact, if on the one hand we have suggested that what is ultimately distinctive in explaining the choice and implementation of rules by the same principals who create and run the organisation is the principals' set of shared values and objectives, on the other hand we have also emphasised that, once defined, rules can reinforce or discourage particular forms of behaviour. Basic institutions, mostly in terms of rights to control strategic decision making, are at the pinnacle of our pyramid.

In developing our three-layer framework for explaining the links between shared values, governance 
choices and individual motivations, we have placed basic institutions, mostly in terms of rights to control strategic decision making, at the basis of our pyramid. At the opposite end of the pyramid, we emphasise that the fulfilment of individual needs and the full expression of individual motivations in an organizational environment is also a result of the interaction with the institutional and organisational spheres. In fact, if on the one hand we have suggested that what is ultimately distinctive in explaining the choice and implementation of rules by the same principals who create and run the organisation is the principals' set of shared values and objectives, on the other hand we have also emphasised that, once defined, rules can reinforce or discourage particular forms of behaviour.

Overall, the reciprocal influences between individual motivations, organisational objectives, and institutional framework have been given special focus because of their role in promoting consistency between the individual and the contextual level, working toward the improvement of individual satisfaction and wellbeing (Dewey, 1917; Deci and Ryan, 2000). We have argued that, internally, the incentive mix offered by non-profit oriented firms should promote the less material leverage of activities, without necessarily the need to lower economic returns. The appraisal of non-material returns, however, does not rule out the need to satisfy individuals on both pecuniary and nonpecuniary grounds. These two complementary dimensions are a crucial aspect of the organisation survival and growth. Rules and routines can provide the mix of modalities for incentivizing both monetary and non-monetary aspects of individual behaviour and for achieving shared goals. Moreover, motivational upholding and individual fulfilment cannot be supported only by the formal distribution of participation rights but needs to be paired by substantive features of the organisation, both internally and externally with respect to other stakeholders.

In considering cooperative firms as entrepreneurial associations driven by self-organised collective action in which members are granted democratic and non-saleable control rights, we have also set the values and objectives of cooperation as the benchmark for assessing formal and less formal governance choices, both internally and externally, as well as the impacts of such choices on individual behaviours and motivations. In dynamic terms, specifically, cooperative governance is oriented towards ensuring that all the members can voice in the decision-making process, thus improving the compatibility between individual and organisational needs and objectives. Democratic participation implies that the outcomes and the procedures concerning each individual member depend on the preferences expressed by other members (Stikkers, 2011). The interconnectedness of results both at the individual level and at the organisational level is recognised by means of mutual dependence and inclusive governance.

Internally, this raises a whole set of questions connected with the rivalrous and non-excludable nature of the resources employed, and of the value added produced by cooperative firms. Our framework acknowledges and explicitly addresses (through the checks and balances of a democratic decision making system) the dangers of opportunism and mismanagement connected with collective choices and the relevance of rules in preventing it. Externally, opportunism may emerge out of production relationships, when the cooperative values are not extended to the governance of inter-firm linkages. The implications for the motivation and behaviour of members within the controlling organisation need to be empirically tested. Specularly, for the firms that "suffer" external control, motivations run the risk of being hollowed out, leading to a decrease in welfare. Elements of external control, beyond membership, have not been given perhaps enough attention in the study of cooperatives. We have argued however that with power unbalances amongst organisations and following processes of growth and internationalisation, the consistency between organisational strategies, the values of cooperation, and membership motivation can be placed at risk and generate tensions across stakeholders. 


\section{REFERENCES}

Bartlett, W., Cable, J., Estrin, S., Jones, D.C. \& Smith, S.C. (1992). Labor-Managed Cooperatives and Private Firms in North Central Italy: an Empirical Comparison. Industrial and Labor Relations Review, 46, 103-18.

Becchetti, L. \& Borzaga, C., 2010 (eds), The economics of social responsibility. The world of social enterprises. London: Routledge.

Becchetti, L. (2010) Dall'homo oeconomicus all'homo reciprocans. Bologna, IT: II Mulino.

Becchetti, L., Castriota, S. \& Tortia, E.C. (2012) Productivity, wages and intrinsic motivation in social enterprises. Small Business Economics. DOI 10.1007/s11187-012-9431-2.

Ben-Ner, A. \& Gui, B. (2003) The theory of nonprofit organisations revisited. In: E. Anheier \& A. BenNer, eds. The Study of the Nonprofit Enterprise: Theory and approaches (pp.3-26) New York: Kluwer Academic/Plenum Publishers.

Ben-Ner, A. \& Jones, D.C. 1995, "Employee Participation, Ownership, and Productivity: A Theoretical Framework", Industrial Relations: A Journal of Economy and Society, vol. 34, no. 4, pp. 532-554.

Ben-Ner, A. \& Putterman, L. (1998) Values and institutions in economic analysis. In: A. Ben-Ner \& L. Putterman, eds. Economics, Values, and Organization (pp. 3-72) Cambridge, MA: Cambridge Univ. Press.

Ben-Ner, A. \& Van Hoomissen, T. 1991, Nonprofit organizations in the mixed economy, Annals of Public and Cooperative Economics, vol. 62, no. 4, pp. 519-550.

Ben-Ner, A. (1993) Organizational reform in Central and Eastern Europe. A Comparative Perspective. Annals of Public and Cooperative Economics, vol. 64, no. 3, pp. 329-366.

Benz, M. 2005, "Not for the Profit, but for the Satisfaction?- Evidence on Worker Well-Being in NonProfit Firms", Kyklos, vol. 58, no. 2, pp. 155-176.

Birchall, J. \& Simmons, R. (2010) The Cooperative Reform in Tanzania and Sri Lanka, Annals of Public and Cooperative Economics, vol. 81, no. 3, pp. 467-500.

Birchall, J. 2010. People-centred businesses: co-operatives, mutuals and the idea of membership. Basingstoke: Palgrave Macmillan.

Bodini, R., Borzaga, C., and Depedri, S. (2010), Cooperatives: the Italian experience. Trento, EURICSE, AP 001/2010. Retriened on 12 March 2012 at: www.euricse.eu

Bonin, J.P., Jones, D.C. \& Putterman, L. (1993) Theoretical and Empirical Studies of Producer Cooperatives: Will Ever the Twain Meet? Journal of Economic Literature, XXXI (September), pp.1290-320.

Book, S.A. \& Ilmonen, K. 1989, "Problems of Contemporary Cooperatives: Consumer Cooperatives in Sweden and Finland 1960-80", Economic and Industrial Democracy, vol. 10, no. 4, pp. 499515.

Borzaga, C., Depedri, S. and Tortia, E. (2011) Organizational Variety in Market Economies and the Role of Cooperative and Social Enterprises: A Plea for Economic Pluralism, in Journal of Cooperative Studies, v. 44, n. 1 (2011), p. 19-30.

Borzaga C., Tortia E., (2010) "The economics of social enterprises: toward a new interpretation" in L. Becchetti, C. Borzaga, (eds.), The Economics of social responsibility. The World of Social Enterprises, Routledge, London, 15-33.

Bruni, L. \& Zamagni, S. (2007) Civil Economy, Efficiency, Equity, Public Happiness. Oxford, UK: Peter Lang.

Burdin, G. \& Dean, A. (2009) New evidence on wages and employment in worker cooperatives compared with capitalist firms. Journal of Comparative Economics, 37, 517-33.

Carpita, M., Depedri, S. \& Tortia, E.C. (2010) Incentives, Job Satisfaction and Performances: Empirical evidence in Italian social enterprises. University of Trento, Department of Economics, mimeo.

CGM Gruppo Cooperativo 2012. Ritardi nei pagamenti. CGM website http://www.consorziocgm.org/news/ritardi-nei-pagamenti, accessed March 2012.

Cornforth, C. 2004, "The Governance of cooperatives and mutual associations: a paradox perspective", Annals of Public and Cooperative Economics, vol. 75, no. 1, pp. 11-32.

Cowling, K. \& Sugden, R. 1998, "The Essence of the Modern Corporation: Markets, Strategic 
Decision-Making and the Theory of the Firm", The Manchester School, vol. 66, no. 1, pp. 59-86.

Craig, B. \& Pencavel, J. (1992) The Behaviour of Worker Cooperatives: the Plywood Companies of Pacific Northwest. The American Economic Review, 82, 1083-105.

Craig, B., \& Pencavel, J. (1994) The Empirical Performance of Orthodox Models of the Firm: Conventional Firms and Worker Cooperatives. Journal of Political Economy, 102, 718-44.

Deci, E.L., \& Ryan, R.M. (2000) Self-determination Theory and the Facilitation of Intrinsic Motivation, Social Development and Well-being. American Psychologist, 55, 68-78.

Degli Antoni, G. (2009). Intrinsic vs. Extrinsic Motivations to Volunteer and Social Capital Formation. Kyklos. Vol. 62 (3). p 359-70.

Dewey John (1977/1917) Creative Intelligence: Essays in the Pragmatic Attitude. Extract reprinted in Sidorsky D (1977) John Dewey Edited by David Sidorsky (pp. 70-95) New York: Harper.

DiMaggio, P.J. \& Powell, W.W. 1983, "The Iron Cage Revisited: Institutional Isomorphism and Collective Rationality in Organizational Fields", American Sociological Review, vol. 48, no. 2, pp. pp. 147-160.

Dow G. K. 2003 Governing the firm: workers' control in theory and practice. Cambridge: Cambridge University Press.

Erdal, D. (2011). Beyond the corporation. Humanity working, London: The Bodley Head.

Ellerman, D. 2005. Translatio vs Concessio. Retrieving the Debate About Contracts of Alienation with an Application to Today's Employment Contract, Politics and Society, vol. 33, no. 3

Errasti, A.M., Heras, I., Bakaikoa, B. \& Elgoibar, P. 2003, "The Internationalisation of Cooperatives: The Case of the Mondragon Cooperative Corporation", Annals of Public and Cooperative Economics, vol. 74, no. 4, pp. 553-584.

Fehr, E., Fischbacher, U. \& Gächter, S. (2002). Strong reciprocity, human cooperation, and the enforcement of social norms. Human Nature, 13, 1-25.

Fehr, E., \& Schmidt, K. (1999). A theory of fairness, competition, and cooperation, Quarterly Journal of Economics, 114 (3): 817-868.

Frey, B.S. \& Jegen, R. 2001, "Motivation crowding theory", Journal of Economic Surveys, vol. 15, no. 5, pp. 589-611.

Frey, B.S. \& Osterloh, M. (1999) Yes, Managers Should be Paid like Bureaucrats. Journal of Management Inquiry, 14, 96-111.

Frey, B.S. (1997), Not just for the money: an economic theory of personal motivation, Cheltenham, Edward Elgar.

Furubotn, E.G. \& Pejovich, S. (1970) Property rights and the behaviour of the firm in socialist State: The example of Yugoslavia. Zeitschrift für Nationalökonomie, 30, 431-54.

Gibbon, J. and Dey, C. 2011 . Developments in social impact measurement in the third sector: scaling up or dumbing down? Social and Environmental Accountability Journal, Vol. 31, No. 1, pp. 6372.

Grant, R. M. (1996) Toward a knowledge-based theory of the firm. Strategic Management Journal 17: 109-122.

Grossman, S.J. \& Hart, O.D. 1986, "The Costs and Benefits of Ownership: A Theory of Vertical and Lateral Integration", Journal of Political Economy, vol. 94, no. 4, pp. pp. 691-719.

Hansmann, H. (1996) The Ownership of the Enterprise. Harvard, MA: Harvard Univ. Press.

Hansmann, H. 2000, The ownership of enterprise, Belknap Press.

Hayashi, Yukinari, Okushima, Shinichiro, Yamada, Akira, Yoshihara, Naoki (2011). Moral Motivation in Public Economic Activities. (In Japanese. With English summary.).Economic Review (Keizai Kenkyu). Vol. 62 (1). p 1-19.

Hernandez, S. 2006, "Striving for Control: Democracy and Oligarchy at a Mexican Cooperative", Economic and Industrial Democracy, vol. 27, no. 1, pp. 105-135.

Hodgson, G.M. (2006) Economics in the Shadows of Darwin and Marx: essays on institutional and evolutionary themes, Cheltenham, UK: Edward Elgar.

Hodgson, G.M. (2007) Institutions and Individuals: Interaction and Evolution. Organization Studies, 28(1), 95-116.

Humphrey J. and Schmitz H. 2004, Governance in global value chains, in Schmitz H. editor, Local enterprises in the global economy, (Edward Elgar, Cheltenham) 
ICA (2012) Co-operative values and principles. ICA website http://www.2012.coop/en/what-coop/co-operative-values-principles, accessed March 2012.

ISTAT 2008. Le cooperative sociali in Italia, anno 2005. Rome: ISTAT (Istituto Nazionale di Statistica) Jämsén, Pekka, Ikäheimo, Seppo and Maninen, Pasi 1999. Capital formation in Kenyan farmerowned cooperatives. A case study. Rome, FAO.

Jensen, M., \& Meckling, W. (1976) Theory of the Firm: Managerial Behaviour, Agency Costs and Ownership Structure. Journal of Financial Economics, 3, 305-60.

Jones, D.C. \& Kalmi, P. (2012) Economies of Scale Versus Participation: A Co-operative Dilemma? Paper presented at the conference organizaed by EURICSE (European Research Institute on Cooperative and Social Enterprises, Trento): "Promoting the Understanding of Cooperatives for a Better World". Venice, San Servolo, March 15-16, 2012.

Jones, D.C. \& Svejnar, J. 1985, "Participation, profit sharing, worker ownership and efficiency in Italian producer cooperatives", Economica, vol. 52, no. 208, pp. 449-465.

Kandathil, G.M. \& Varman, R. 2007, Contradictions of Employee Involvement, Information Sharing and Expectations: A Case Study of an Indian Worker Cooperative, Economic and Industrial Democracy, vol. 28, no. 1, pp. 140-174.

Kogut, B. and Zander, U. (1992) Knowledge of the Firm, Combinative Capabilities, and the Replication of Technology, Organization Science, 3(3): 383-397.

Kreps, D.M. (1990) Corporate culture and economic theory: In: J.E. Alt \& K.A. Shepsle, eds. Perspectives on Positive Political Economy (pp.90-143) Cambridge, MA: Cambridge Univ, Press.

Lazear, E-P. \& Shaw, K.L. (2007) Personnel economics: the economist view of human resources., Journal of economic perspectives, 21, 91-114.

Leete, L. (2000) Wage Equity and Employment Motivation in Nonprofit and Forprofit Organizations. Journal of Economic Behavior and Organization, 43, 423-446.

Leibenstein, H. (1966) Allocative efficiency vs. "X-efficiency, American Economic Review, 56(3): 392415.

Lima, J.C. 2007, "Workers' Cooperatives in Brazil: Autonomy vs Precariousness", Economic and Industrial Democracy, vol. 28, no. 4, pp. 589-621.

Markusen A. 1996, Sticky places in slippery space: a typology of industrial districts,' Economic Geography Vol. 72, No. 2, 294-314.

Mas, A. and Moretti, E. (2009). Peers at work. The American Economic Review, 99:1, 112-145.

Meidinger, C., Rulliere, J.-L., Villeval, M.-C. (2000). Free-Riding and Fairness in Principal-Multi-agent Relationships: Experimental Evidence. Rivista Internazionale di Scienze Sociali. Vol. 108 (4). p 40934.

Menzani T. and Zamagni V. (2010) Cooperative Networks in the Italian Economy. Enterprise and Society 11(1), 98-127.

Mirovski, P. (1987) The Philosophical Basis of Institutional Economics. Journal of Economic Issues, 21, $1001-1038$.

Mohnen, Alwine, Pokorny, Kathrin, and Sliwka, Dirk (2008). Transparency, Inequity Aversion, and the Dynamics of Peer Pressure in Teams: Theory and Evidence. Journal of Labor Economics, Vol. 26, No. 4 (October), pp. 693-720.

Morrison, R., (1991), We Build the Road as We Travel: Mondragon, a Cooperative Social System, Philadelphia, New Society.

Nahapiet J. and Goshal, S. (1998) Social capital, intellectual capital and organizational advantage. Academy of Management Review 23(2):242-266.

Navarra, C. (2010) Collective Accumulation of Capital in Italian Worker Cooperatives Between Employment Insurance and "We-rationality": An Empirical Investigation. [Online] Trento: EURICSE $\begin{array}{lllll}\text { Working Paper } & 4 & 2010 . & \text { Retrieved }\end{array}$ http://www.euricse.eu/sites/default/files/db uploads/documents/1267106823 n350.pdf. [Accessed 25 May 2010].

Nicholls, A. 2010, "Institutionalizing social entrepreneurship in regulatory space: Reporting and disclosure by community interest companies", Accounting, Organizations and Society, vol. 35, no. 4, pp. 394-415.

Olson, M. (1971) The Logic of Collective Action. Public Goods and the Theory of Groups. New York: Schocken Books. 
Ostrom, E.(1990) Governing the Commons. The evolution of institutions for collective action. Cambridge, MA: Cambridge Univ. Press.

Ostrom, E. 2010. "Beyond Markets and States: Polycentric Governance of Complex Economic Systems." American Economic Review, 100(3): 641-72.

Parrilli, M. D. and Sacchetti, S. 2008. Linking learning with governance in networks and clusters: key issues for analysis and policy. Entrepreneurship and Regional Development Vol. 20, No. 4, 387408.

Pencavel, J., Pistaferri, L., \& Schivardi, F. (2006) Wages, Employment, and Capital in Capitalist and Worker-Owned Firms. Industrial \& Labor Relations Review, 60, 23-44.

Penrose E.T. 1995 [1959], The Theory of the Growth of the Firm. (Oxford: Blackwell)

Putterman, L., 1988. The Firm as Association versus the Firm as Commodity. Efficiency, Rights and Ownership. Economics and Philosophy, 4, 243-266.

Richardson, G.B. 1972, "The Organisation of Industry", The Economic Journal, vol. 82, no. 327, pp. pp. 883-896.

Role of Co-operative and Social Enterprises: A Plea for Economic Pluralism. Journal of Cooperative Studies, 44, 19-30.

Rose-Ackerman, S. (1996) Altruism, Non profits, and Economic Theory. Journal of Economic Literature, 34, 701-728.

Russell, R. 1991, "The Role of Support Organizations in the Development of Cooperatives in Israel", Economic and Industrial Democracy, vol. 12, no. 3, pp. 385-404.

Sacchetti S. and Sugden R. 2003, The Governance of Networks and Economic Power: The Nature and Impact of Subcontracting Relationships, Journal of Economic Surveys, Vol. 17, No. 5, pp. 669-91.

Sacchetti, F.; Sacchetti, S \& Sugden, R. (2009) Creativity in Socio-Economic Development: Space for the Interests of Publics. International Review of Applied Economics, 23, 653-72.

Sacchetti, S. \& Sugden, R. 2009. The Organization of Production and Its Publics: Mental Proximity, Markets and Hierarchies. Review of Social Economy, 67, 289-311.

Sacchetti, S. and Tortia, E.C. (2011) Satisfaction with creativity: a study of organisational characteristics and individual motivations. Trento, Discussion Paper no. 09/11. Retrieved on April $13^{\text {th }}, 2012$ at: http://www.unitn.it/deco/15312/discussion-papers-2011

Simon, H.A. (1979) Models of thought. New Haven, CT: Yale University Press.

Spear, R. 2004, "Governance in Democratic Member-Based Organisations", Annals of Public and Cooperative Economics, vol. 75, no. 1, pp. 33-60.

Spear, R., Cornforth, C. \& Aiken, M. 2009, The Governance Challenges of Social Enterprises: Evidence from an UK Empirical Study, Annals of Public and Cooperative Economics, vol. 80, no. 2, pp. 247-273.

Speckbacher, G. 2008, "Nonprofit versus corporate governance: An economic approach", Nonprofit Management and Leadership, vol. 18, no. 3, pp. 295-320.

Stiglitz, J. (2009) Moving Beyond Market Fundamentalism To A More Balanced Economy. Annals Of Public and Cooperative Economics, 80, 345-60.

Stikkers, K.W. (2011), Dewey, Economic Democracy, and the Mondragon Cooperatives, European Journal of Pragmatism and American Philosophy, 3 (2): 186-199.

Tortia, E.C. (2011) The firm as a common. The case of accumulation and use of common resources in mutual benefit organizations. Trento, Discussion Paper no. 12/11. Retrieved on April 13 ${ }^{\text {th }}$, 2012 at: http://www.unitn.it/deco/15312/discussion-papers-2011

Unioncamere 2010. Rapporto Unioncamere 2010, Centro Studi Unioncamere, Rome.

Valentinov, V. (2007) The property rights approach to nonprofit organisations: the role of intrinsic motivation. Public Organisation Review, 7, 41-55.

Valentinov, V. (2008) The economics of the non-distribution constraint: a critical reappraisal. Annals of Public and Cooperative Economics, 79, 35-52.

Vanek, J. (1970) The General Theory of Labour Managed Market Economies. Ithaca, NY: Cornell Univ. Press.

Von Pischke, J. D. Rouse, John G. 2004. New strategies for mobilizing capital in agricultural cooperatives. Rome: FAO

Wanyama, F.O., Develtere, P. \& Pollet, I. 2009, Reinventing the Wheel? African cooperatives in a liberalized economy. Annals of Public and Cooperative Economics, vol. 80, no. 3, pp. 361-392. 
Williamson, O.E. (1987) The Economic Institutions of Capitalism, New York: The Free Press.

Williamson, O.E. (2000) The new institutional economics: Taking stock, looking ahead. Journal of Economic Literature, 38, 595-613. 